\title{
Gender, Feminism and the Girl-Child
}

\author{
Shuaibu Ramat Sule \\ Mohammed Abubakar \\ Department of General Studies, Federal Polytechnic, Bali,Taraba State, Nigeria
}

\section{Doi:10.5901/mjss.2014.v5n26p28}

\section{Abstract}

The human society is made up of men and women created to live as partners but it is widely recognized that women are in subordinate position in societies. Gender discriminations against women and the struggle to achieve equality with men in social, economic and political advancement remains an undying issue in societies. The paper explores the roots of patriarchy, domains of women's deprivations and their negotiations in societies. It concludes by foregrounding the position of women in the society and offers ways to assist their equal and balance development with men.

\section{Gender}

Most societies of the world have patriarchal heritage, a social, political, economic and cultural order in which authority, rights, and privileges are dominated by men. It is widely accepted that women live in men's world because the values of societies are mostly dictated from men's view of the world. Alcoff (1988.406) sorrowfully gives a picture of men's abounding power on women in the following ways, "Man has said that women can be defined, delineated, captured, understood, explained and diagnosed to level of determination never accorded to man himself, who is concerned as a rational animal with free will." Alcoff's accusation shows that beneath the inseparable relationship between men and women either as husbands and wives, sisters and brothers, mothers and sons, or fathers and daughters, there lies a conflict of gender inequality and imbalance. It has undermined the humanity of women, their achievement and happiness in life. Gender inequality and the struggle to eliminate it is a topical issue in societies.

Many explanations have been given for the roots of patriarchy. The sources range from religion, views of philosophers, culture and historical development of societies. A society's patriarchy may be rooted in a complex of sources.

The religious source of patriarchy is contentious. In the Judeo-Christian world, women were presented in subordinate and negative images. In Genesis, God created man, Adam first and from his rib (Adam's rib), He created the woman, Eve (Genesis 2:21-22). In Genesis, too, (3:17 - 19), the fall of man was facilitated by Eve. Similarly, the subordinate position of women in the New Testament can be found in the teachings of St. Paul:

Women should listen and learn quietly and submissively. I do not let women teach men or have authority over them. Let them listen quietly. For God made Adam first and afterwards He made Eve. And it was the woman, and not Adam who was deceived by Satan and sin was the result (1 Timothy 2:11 - 13).

In 1 Corinthians (14:34-35) St. Paul writes:

Women should be silent during Church meetings. It is not proper for them to speak. They should be submissive as the law says. If they have any question to ask, let them ask their husbands at home for it is improper for women to speak in church meetings.

Although the above verses show man's superiority and authority over women, Christian feminism challenges men's dominance in the Church and the claim of women's moral deficiency by invoking some teachings in the Bible. For instance, Galatians 3:28 states that "There is neither...male or female for all are one in Christ Jesus".

Apart from the Biblical teachings shown here which many believe have propelled the thinking that women are inferior human beings, there are ideas of some past religious leaders and leading philosophers of the West. Christian philosophers and leaders like Thomas Aquinas and St. Augustine asserted that women were "imperfect men" and that they possess sensual character that inhibits men's attainment of spiritual power and greatness (Bressler 1994:180-181). Aristotle is quoted (in Bressler, pp.180-181) as saying "...the male is by nature superior, and the female inferior and the 
one rules and the other is ruled". Rosseau in Bryson (1992:22) believed that women are different in their nature and abilities and that men should be citizens while women become wives and mothers. Proudhon, a French philosopher, believed that women could only have two roles, that of the housewife or harlot (Bryson, p.50).

Although there is a claim of the elevation of the status of the women-folk in the religion of Islam, the religion cannot be ignored as a contributor to the development of the patriarchal order in some societies. Afza (1969: 9 - 10) writes:

In the religions of the world, Islam is the only exception which gave the attribute "better half" to woman and established her a separate identity, thus giving her an independent and honourable status. Islam not only dignified the status but also raised the status of woman to a footing of near equality with man.... It was Islam that for the first time vindicated the rights of women and gave them a status unknown, un-thought of even to this day. They are granted all the fundamental rights.... There is no other religion in the world that favours women so much as Islam.

In spite of this claim, El Sadawi (1997: 80 - 84) draws our attention to some patriarchal traditions in Islam. Polygamy is allowed for men and children are attributed to their father. Islam allows a man to marry a Christian or a Jewish woman who belongs to the people of the Book but a woman is not permitted to marry a man who is not a Muslim. For inheritance, the man has twice the fortune of a woman.

Culture is another source of patriarchy. In many African cultures, women are given negative images. For instance, in the undiluted traditional society of the Igala people in Kogi State of Nigeria, the containers or buckets women used in bathing were not allowed to be kept in the compound but in the backyard. The reason was that if such containers were kept in the compound, they would defile some protective medicines or fetishes buried or hung in the compound. Again, girls who have attained the age of puberty are not allowed to enter certain shrines like the shrine of the ancestral masquerade known as "Egwu Afia".

Yet, others have traced women's subjugation to history. Maren (1994:49) writes, ".... when civilization moved from an economy based on collecting and hunting to agricultural and pastoral economy, child-bearing women were put in a dependent situation from which the dominant males have never allowed escape."

Some Marxists have argued that women's subjugation by men is traceable to European colonialism. Engels Fredrick quoted in Alkali (1995:20) explained that colonialization introduced "private property, commodity production and other materialistic values which constituted capitalism and sexual inequality". Awe's view (1992) in Alkali, (p.26) that colonialism removed women in West Africa from a "dynamic" and "constructive" role to a subordinate position is supportive of the Marxist explanation of the origin of women's subjugation by men.

\section{Feminism}

Feminism can briefly be defined as discriminations against women and the struggle to eliminate them. As a concept, it is western in origin but has spread all over the world. Its history is vast but a cursory historical excursion of this great movement is expedient. Feminist thought dates back to the medieval time but was first raised by men. The thought started gathering momentum in the $14^{\text {th }}$ century when a French woman, Christie De Pisan (1364 - 1430) wrote a book concerning the rights and duties of women. Mary Astell (1666 - 1731), an English woman also wrote a book making pleas for women. There were several women and men who spoke concerning the need to improve the lot of women thereafter (Bryson, pp $1-26)$.

In 1792, Mary Wollstonecraft co-authored a book with John Stuart Mill, The Rights of Woman and the Subjection of Women in which they criticized the subjugation of women by men and maintained that women's subordinate position was not rooted in her biology but originated from differences in the education and orientation given to boys and girls (Alkali, p.15). Feminism in Europe became well articulated in the late $19^{\text {th }}$ century when women started movements advocating and demanding for several reforms and rights in such areas as education, suffrage and property ownership. The fight for women's rights has spread all over the world because virtually every society has a heritage of women subjugation.

The history of ancient Europe is replete with different acts of maltreatment of women as stated below:

In most part of western history, women were discriminated against. In ancient Europe, the women had no right to study or be involved in public life. At the end of the $19^{\text {th }}$ century, women in France were forced to put on veils in public places. In Germany, men had the right to sell their wives. American women had no voting right. Women were not allowed to do business except with male representatives: brothers, husband, father or son. Women had no authority over their children. They had little or no access to education. Most professions were for men. (Feminism, Encyclopaedia, Britanica, 2008, ultimate suite).

Today, undoubtedly, it can be said that women in the West have made appreciable progress in the struggle for equal rights with men. However, the 1996 US Department of Justice Report in Zweig and others (2007:1149) showed that crimes against women ranging from domestic violence, rape, sexual assault and robbery were still on the increase. 
Women in the West therefore still face problems created for them by men.

Arabs, before and after Islam, had and still have practices that are detrimental to women. Rahim (1983.7) writes:

The position of women was very degrading in Arab society. They were treated as chattels and with contempt. The birth of a female child was considered as a great curse and she was often buried alive by the heartless father. Women could not have any share of the property of the husbands or the fathers... the women of the pre-Islamic days had no status in the Society.

Centuries after the coming of Islam, the condition of the Arab women is still gloomy. El Sadawi (1997:235) has maintained that Arab women are treated as objects and that they operate at the fringes of the society. The women are slaves and men are masters.

Africa in general and Nigeria in particular have many spheres of women marginalization by men. Diwa (1991:9), quoting Imam (1985) to depict the subordinate position of women in Nigeria has said that "All over the country women are regarded as the "property" of first their fathers and then their husbands ... for things that an individual male can get on his merit, a woman has to first obtain her father's/husband's permission. For example, to get a passport or visa: to obtain a bank loan: to get a scholarship or to exercise rights over her own issues (children)."

Since independence, Nigeria's political arena has been dominated by men: men have been presidents, governors, ministers, legislators and local government chairmen. Admittedly, women have made remarkable progress in the acquisition of Western education and getting paid jobs and in very recent times made appreciable entry into politics. There are however, several forms of maltreatment women still undergo in the hands of men in Nigeria. Some of these are "child marriage", awful widowhood rites, seclusion and mutilation of the female genital in some parts of the country, rape, reckless polygamy, and rampant cases of divorce.

Muhammad (2007:56), has lamented the abuse of womanhood and the Islamic concept of polygamy by Africans, especially Hausa-Fulani Muslims. Basing his anguish and condemnation on the increasing record of divorce cases in Kano State, he maintained that parents were recklessly giving out their daughters for marriage just as men marry many wives without having the financial capacity to maintain them.

The shocking treatment of Nigerian women is legion. The Nation (2013:2-3) reports from the U.S 2013 Trafficking in Persons Report, "... women and girls are trafficked for domestic servitude and sex trafficking .... Nigerian women and girls primarily from Benin City in Edo State are subjected to forced prostitution in Italy while Nigerian women and girls from other states are subjected to forced prostitution in Spain, Scotland, the Netherlands..."

Raping of girls is on the increase in Nigeria. The physical and psychological trauma this act inflicts on the girl child notwithstanding, most victims and their parents shy away from fighting rapists in the law courts because it is seen that such battle exposes the woman and her family to public shame. Enwegbare (2013:24) tells of one of many rape incidents in Nigeria, "one of my worst experiences is the case of a young Nigerian girl found one day weeping profusely for being raped at the Abuja's five star hotels as she was performing her cleaning duty in one of the rooms."

'Baby factories` are growing in Nigeria particularly the eastern part of the country. Daily Trust (2013:3) reports the discovery of a baby factory in Umuezeala Umuaka in Njaba Local Government Area of Imo State in which 26 pregnant teenagers were found. The factory was reportedly run by a Mrs Comfort Ahamefula to produce babies for sale. It is a sad irony that a woman partakes in the acts of dehumanization of women. The Nation (P.60) equally reports the discovery of a "baby factory" named Cross Foundation International in Aba, Abia state in which 16 expectant mothers including teenagers were found.

An important thing to point out at this juncture is that the maltreatment of women is a persistent issue in many societies. The nature and level of women's maltreatment in different societies may differ from one to the other. The struggle to dislodge patriarchy is however, ubiquitous. Indeed, feminism has long been internationalized. In 1946, the United Nations established a commission on the status of women. In 1948, the UN issued its Universal Declaration of Human Rights and this includes the protection of men and women. In 1993, there was an International Conference of Women in Beijing, China, to discuss and take common action on issues affecting women (see Feminism, International Feminism, Wikipedia, 2001). On October 14, 2013 the U.N declared campaign to end sexual violence against women.

In 1982, Arab Women's Solidarity Association (AWSA) was established in Egypt (El Sadawi, p.36). In Nigeria, there are many women organizations: Network for Women Studies in Nigeria (WIN) formed in Zaria in 1982, National Coalition on Violence against Women established in 2007 (Adamu, 2007). Other organizations involved in researches, and activities to eliminate maltreatment of women and children in Nigeria are Women Trafficking and Child Labour Eradication Foundation (WOTCLEF) and The National Agency for the Prohibition of Trafficking in persons (NAPTIP) 


\section{The Girl-Child}

The recent world population is $7,149,178,200$ with the males constituting $50.4 \%$ while the females are $49.6 \%$ (retrieved from http:/country metres.info/en/world, 2014). Nigeria`s population by 2006 census was 140,000,000 with the males constituting $51.26 \%$ and the females $48.79 \%$ (retrieved from http//nigerianpolity.blogspot.com.../Nigeria, 2014). From this account, it can be seen that the population of the males is only slightly higher than that of females either in Nigeria or the world at large. Human societies are engaged in eternal battle for sustainable development and happiness. No society can be said to be sustainably developed if $49 \%$ of its population is undermined, helpless and sad. A development that puts men in dominance but women on the fringes of the society is a travesty of justice and is detrimental to the society because it cannot endure. Ecclesiastes (8:9) of the Holy Bible in The Watchtower (2014:11) says, "Man has dominated man to his harm" just as Usman Danfodio in Chris (2010) said, "A kingdom may endure with unbelief, but it cannot with injustice."

Moreover, the destiny of the girl-child should attract a serious concern in the society because they are delicate, yet have enormous resources and responsibilities. They have the capacity for proper and careful planning. They are diligent in management; they love and particularly train the young ones better than men even as they are mothers. Because of their enormous responsibilities, they need to be empowered educationally and economically. The Nigeria National Policy on Education (2004:7) says, "education fosters the worth and development of the individual, for each individual sake, and for the general development of the society." Women's educational empowerment therefore is of primacy in the efforts to achieve gender equality because at the base of women's plight in the society is their weak possession of educational power. The empowerment of women in literacy vocational skills will raise social status and enable to function effectively in the development of the society.

What is more, advocacies and legislations that have been put in place to cripple maltreatment and discriminations against women should not only be sustained but strengthened. The society must continue to interrogate and expose the socio-political roots of women's underdevelopment in order to achieve women's equality with men. Finally, the womenfolk can do a lot in the fight against rape in the society. Decent dressing which is a canon of morality in traditional and religious societies is fast eroding. It is unfortunate that in our time, in the name of freedom and fashion, a lot of women dress naked, exposing the sensuous part of their anatomy, seemingly taunting men for sex. The woman is naturally a centre of attraction and love without immodest dressing. Modest dressings can curtail the incidence of raping of women in the society.

\section{References}

Adamu, F. (2007). "Feminist Essay Review". http://www.feministafrica.org. 2 Level.

Afza, N. \& Ahmed, K. (1969). The Position of women in Islam: A Comparative Study. Karachi: Nawa-I Wagt Printers.

Alcoff, L. (1988). "Cultural Feminism versus Post-structuralism: The Identity Crisis in Feminist Theory". The University of Chicago press. Retrieved 2006 Oct, $15<$ htt/links.jstor.org/sci?

Alkali, Z. (1995).Feminism and the Novels of El sadawi Nawal.Unpublished Doctoral Thesis.Post-Graduate School, Bayero University, Kano.

Bressler, C. (1994). Literary Criticism: An Introduction to Theory and Practice (2nd Edition). New Jersey: Prentice Hall.

Bryson, V. (1992).Feminist Political Theory.London: Macmillan Press.

Christian Feminism (2008)http://en.wikipedia.or/wiki

Chris,W.(2010)."Understanding Boko Haram" Retrieived Feb, 2014 from Chrisngwodo.blogspot.com/.../understanding Bokoharamtheology-of-ht...

Daily Trust (2013:May 3). Daily Trust Vol. 32, No. 20. P. 3 Abuja: Media Trust Limited.

Diwa, M. I. (1991). The Nature of Feminism in Buchi Emechetta's Novels. Unpublished Masters Dissertation.Post-Graduate School, University of Maiduguri.

El sadawi, N. (1997). The Nawal El sadawi Reader.London: Zed Books.

Enwegbara, O.(2013,December 10). "The Alien Bill of Nigeria".Leadership.No.2091. P.24. Abuja: Leadership Group Limited.

Feminism Judeo-Christian Patriarchy (2008)http://en.wikipedia.or/wiki

Federal Republic of Nigeria (2004).National Policy on Education. Abuja:Federal Ministry of Education Press.

Holy Bible: New Living Translation. Gift and Award Edition (1996). Wheaton Illinois.

Maren, L. Carden (1974). The New Feminist Movement.New York:Russel Sage Foundation.

Muhammad, B. (June 23, 2007). "One Man Four wives. Weekly Trust.Vol 10, No.34. Abuja: Media Trust Nig.

Rahim, A. (2001). Islamic History.Lagos: Islamic Publications Bureau.

The Nation (2013, June 20). The Nation.Vol. 8, No. 2522.PP.2-3. Abuja: Vintage Press Limited

Watchtower Bible and Tract Society. (2014, February 1). The Watchtower. Vol. 135,No.3.P.11. New York: Watchtower Bible and Tract 
Society.

Zweig, M. J. \& Burt, R. M. (2007)."Predicting Women's perceptions of Domestic Violence and Sexual Assault Agency Helpfulness".Violence Against Women: An International and Interdisciplinary Journal. Vol. 13, No.11. Los Angeles: Sage Publications.

Shuaib, R. S. (2012)."Feminist Agenda in the Novels of Ikonne, Gimba and Osanyin".Unpublished Master Degree Dissertation.Postgraduate School.University of Maiduguri. 